Pak. j. sci. ind. res. Ser. B: biol. sci. 2019 62B(1) 1-7

\title{
Maximizing Onion Seed Production Through Foliar Application of Zinc and Boron
}

\author{
Khan Zamana, Muhammad Tariq ${ }^{\mathrm{a}}$, Muhammad Arshad Khan ${ }^{\mathrm{b}}$, Muhammad Mansoor ${ }^{\mathrm{b} *}$ \\ Roshan Alic, Muhammad Jamil ${ }^{b}$, Muhammad Yaqoob and Muhammad Waheed ${ }^{a}$ \\ ${ }^{a}$ Department of Soil and Environmental Sciences, The University of Agriculture, Peshawar, Pakistan \\ ${ }^{\mathrm{b}}$ Arid Zone Research Centre, Pakistan Agricultural Research Council, Dera Ismail Khan, Pakistan \\ ${ }^{c}$ Agricultural Research Institute, Mingora, Swat, Khyber Pakhtunkhwa, Pakistan
}

(received September 8, 2017; revised January 9, 2018; accepted January 11, 2018)

\begin{abstract}
Maximizing onion (Allium cepa L.) seed production through foliar application of zinc and boron in Swat Valley at Agricultural Research Institute Mingora-Swat, Pakistan was executed during 2013-14. The onion bulbs of cv. Swat-1 were used as planting material. NPK applied @ 120:60:60 kg/ha as urea, di-ammonium phosphate and potassium sulphate, respectively, while zinc was applied @ 0, 0.3,0.7 kg/ha as heptahydrated zinc sulphate $\left(\mathrm{ZnSO}_{4} .7 \mathrm{H}_{2} \mathrm{O}\right)$ and $0,0.1,0.3 \mathrm{~kg} /$ ha boron in the form of borax $\left(\mathrm{H}_{3} \mathrm{BO}_{3}\right)$. Randomized complete block design was used for the experiment with factorial arrangement and replicated 3 times. $3 \times 4 \mathrm{~m}$ was the plot size. Results revealed that both zinc and boron significantly affected all the parameters under studied. However, maximum number of leaves/plant, maximum number of flowers/plant, maximum seeds/umbel, maximum seed weight/umbel and maximum seed yield were recorded by the combined application of $\mathrm{Zn}$ and $\mathrm{B}$ at 0.7 and $0.3 \mathrm{~kg} / \mathrm{ha}$, respectively. Moreover, maximum concentration of zinc in seeds were found in treatment plots where Zn@0.7 kg/ha and B@0.3 kg/ha were applied simultaneously. Zinc-boron concentration in leaves at flowering stage and in seeds at harvest showed significant positive linear relationship to each other. The results suggested that maximum onion seeds yield under the condition of the experiment were produced when $0.7 \mathrm{~kg} / \mathrm{ha} \mathrm{Zn}$ and $0.3 \mathrm{~kg} / \mathrm{ha}$ boron were applied.
\end{abstract}

Keywords: onionseed, foliar application, zinc, boron, chemical fertilizers

\section{Introduction}

Onion (Allium cepa L.) belonging to the family Alliaceae is the third most important cultivated vegetable crop with a global yield of dry bulbs 88 million tonnes (FAO, 2014). Onion has 13 medicinal and functional properties due to the presence of various biochemical constituents (Lanzotti, 2006). Onion is biennial and it is better to select a good quality bulb for the production of onion seeds. Bulbs are produced from seed in one season and replanted to produce seed in another season. Seed has a unique role to increase onion production. Improved seed contributes substantially to enhance crop yield as high as 30\% (Shaikh et al., 2002). Boron and zinc have pivotal role in pollination and seed set processes, so that their inadequacy can cause decrease in seed formation and subsequent yield reduction. It is well understood from the reported soil fertility survey that the physicochemical conditions of Khyber Pakhtunkhwa soils are not conducive to micro nutrients availabilities (Munir et al., 2006). Zinc has a protective role against the toxic effect of boron concentration in the root

*Author for correspondence;

E-mail: joyadkpk@googlemail.com environment (Singh et al., 1990; Graham et al., 1987). But such a study has not been carried out in detail in this region on crop like onion under field conditions, which is susceptible to zinc and boron deficiencies. Besides deficiency, boron toxicity has also been reported in our soils (Sillanpaa, 1982). Therefore, the low level of available zinc with high level boron is responsible when occurred simultaneously for the crop during growth. However, these imbalances in the levels of zinc-boron may create interactions in soil-plant system which ultimately affects the crop production. Secondly, micronutrients such as zinc-boron applied to soil surface may be of little use. Because of low organic matter content, calcareous nature and alkaline reactions in soils and adsorption of zinc-boron, these conditions are not favorable to micronutrients availability to crops. However, on such soils the micronutrients application as foliar is a precious tool for fighting against the deficiency of the micronutrients. Foliar application is advantageous over soil application due to rapid response, effectiveness and abolition of deficiency symptoms. Foliar application enhances plant growth and yield due to the presence of various micronutrients. Nutrients are 
generally quickly available to the plants by the foliar application than the soil application (Silberbush, 2002). The micronutrients when applied on foliar can be 6 to 20 times more effective than its application to the soil (Liew, 1988). This experiment has been designed to maximize the seed production of onion through foliar application of zinc and boron growing at Swat valley, to determine the zinc-boron interactions on the concentration and total uptake of these trace elements in onion plants.

\section{Materials and Methods}

Randomized complete block design was used for the experiment and replicated three times. $3 \times 4 \mathrm{~m}$ was the plot size having $75 \mathrm{~cm}$ row-row distance and plantplant distance was $30 \mathrm{~cm}$. Before sowing, all the experimental treatments plots were thoroughly ploughed and then proper leveling was done for the application of fertilizers. The test crop was onion (cv. Swat-I).

Fertilizer application. Except nitrogen all the fertilizers were applied at sowing time. The nitrogen was applied at 2 splits. Half of the nitrogen dose was applied at sowing time and half was applied at earthening up stage. The source for NPK was urea, di-ammonium phosphate and potassium sulphate, respectively. Zinc and boron were applied as a foliar spray 150 days after sowing of the crop. For zinc and boron, heptahydrated zinc sulphate $\left(\mathrm{ZnSO}_{4} \cdot 7 \mathrm{H}_{2} \mathrm{O}\right)$ and borax $\left(\mathrm{H}_{3} \mathrm{BO}_{3}\right)$ were used.

Yield and yield parameters. The morphological characters of onion crop such as number of leaves/plant, days to flowering, number of flowers/plant, number of seeds/umbel, seeds weight (g)/umbel and seed yield/plot were studied.

Soil analysis. At the depth of $(0-15 \mathrm{~cm})$ a composite soil sample was taken from the experimental field before sowing. The sample was analyzed for different physicochemical properties like electrical conductivity (EC), soil texture, lime content, soil $\mathrm{pH}$, AB-DTPA extractableZn (Sultanpour and Schwab, 1977), organic matter and extractable boron (Ryan et al., 2001).

Leaf analysis. Five leaves were collected randomly from each sub-plot at flowering stage, cleaned by distilled water, air dried and dried in oven at $70{ }^{\circ} \mathrm{C}$ for $48 \mathrm{~h}$. Leaves were then ground by grinder, packed and analyzed for $\mathrm{Zn}$ according to Isaac and Kerber (1971) and for B according to Bingham (1982), respectively.
Seeds analysis. Seeds were collected randomly from each treatment plot at harvest then cleaned, air dried, ground, packed and analyzed for $\mathrm{Zn}$ and $\mathrm{B}$.

Statistical analysis. A computer package statistics version 8.1 was used for analyzing field and laboratory data by ANOVA technique and means were compared by using least significant difference test for having significant difference among the treatments. In addition, linear regression models were used between zinc-boron relationships (Steel et al., 1997).

\section{Results and Discussion}

Regarding results of the original soil, the soil was silt loam in texture, moderate in organic matter, non-saline, slightly acidic in reaction, moderate in AB-DTPA extractable- $\mathrm{Zn}$, moderately calcareous and deficient in $\mathrm{HCl}$ extractable B (Table 1).

Agronomic parameters. Number of leaves/plant. Data taken on number of leaves/plant of onion are shown in Table 2. It is obvious from the statistical analysis of the data that both $\mathrm{Zn}$ and $\mathrm{B}$ has significantly affected number of leaves. In case of $\mathrm{Zn}$, maximum numbers of leaves were obtained by $\mathrm{Zn} 0.7 \mathrm{~kg} / \mathrm{ha}$ (52.544) leaves/plant, while minimum were obtained by $\mathrm{Zn} 0 \mathrm{~kg} / \mathrm{ha}$ (48.40) leaves/plant. Significant variations were found in respect of number of leaves/plant. In case of $B$, maximum numbers of leaves were obtained by B $0.3 \mathrm{~kg} / \mathrm{ha}$ (56.122) leaves/plant and minimum numbers of leaves were obtained by B $0 \mathrm{~kg} / \mathrm{ha}$ (45.833) leaves/plant. The interaction effect of zinc and boron $(\mathrm{Zn} \times \mathrm{B})$ on number of leaves/plant was 10 also statistically non-significant.

Table 1. Physicochemical properties of original soil used for study

\begin{tabular}{ll}
\hline \hline Soil properties & Values \\
\hline Sand(\%) & 3.2 \\
Clay(\%) & 26.8 \\
Silt(\%) & 70 \\
Soil texture & Silt loam \\
pH & 6.5 \\
EC $(\mathrm{dS} / \mathrm{m})$ & 0.06 \\
Organic matter(\%) & 1.2 \\
Lime $(\%)$ & 2.6 \\
Total nitrogen(\%) & 0.03 \\
Phosphorous $(\mathrm{Mehlic}-3)(\mathrm{mg} / \mathrm{kg})$ & 30.6 \\
Potassium(Mehlic-3)(mg/kg) & 70 \\
AB-DTPA extractable-Zn $(\mathrm{mg} / \mathrm{kg})$ & 1.35 \\
Dilute HCl-B $(\mathrm{mg} / \mathrm{kg})$ & 0.36 \\
\hline \hline
\end{tabular}


The maximum number of leaves were obtained by $\mathrm{Zn}$ $0.7 \mathrm{~kg} / \mathrm{ha}, \mathrm{B} 0.3 \mathrm{~kg} / \mathrm{ha}(59.733)$ leaves/plant, followed by $\mathrm{Zn} 0.7$ * B 0.1 (50.50) leaves/plant, while the minimum were obtained by Zn $0 *$ B 0 (43.833) leaves/plant. This may be happened because of the biochemical role of zinc and boron in plants. These results are in connectivity with Mukesh and Das (2000) who reported that the number of leaves/plant increased with the application of zinc at higher dose and Chowdhury et al. (2004) reported that the number of leaves/plant increased with the application of boron at higher dose.

Days to flowering. Data recorded on days to flowering of onion crop are presented in Table 2. Results of the data recorded on days to flowering showed that both $\mathrm{Zn}$ and $\mathrm{B}$ have significant effects. Statistically significant variations were observed due to the effect of zinc on days to flowering. The longest time (175.33days) were taken when $\mathrm{Zn}$ was applied at the rate 6 of $0 \mathrm{~kg} / \mathrm{ha}$ and shortest time (170 days) was required for $0.3 \mathrm{~kg} \mathrm{Zn} / \mathrm{ha}$. Khan et al. (2007) reported that days to flowering decreased with the application of zinc at the rate of 5 $\mathrm{kg} / \mathrm{ha}$. Results also showed main effect of boron on days to flowering. Minimum time (167 days) from the planting to $50 \%$ flowering was required by the application of $0.3 \mathrm{~kg} / \mathrm{h}$ boron and maximum time (175 days) for days to flowering was required with the application of $0 \mathrm{~kg} / \mathrm{ha}$ boron. Mishra et al. (1990) reported that days required to flowering decreased with the application of boron at higher dose. Jana and Mukhopadhaya (2002) also reported that days to flowering decreased with the application of zinc and boron at higher dose.

Numbers of flowers/plant. The data pertaining to the number of flowers/plant were analyzed and shown in Table 2. Statistical analysis of the data showed that both $\mathrm{Zn}$ and $\mathrm{B}$ have significant effect on number of flowers/plant. From the results, it appeared that the plants received $\mathrm{Zn}$ at $0.7 \mathrm{~kg} / \mathrm{ha}$ produced the maximum number of flowers (19.44)/plant which was significantly different from other treatment plots and the control plants produced the lowest number of flowers (18.21)/plant. Mukesh et al. (2000) reported that number of flowers/plant increased with the application of zinc at higher dose. Rashid et al. (2007) stated that when boron was applied at the rate of $5 \mathrm{~kg} / \mathrm{ha}$ it increased number of flowers/plant. The interaction effects of zinc and boron on the number of flower/plant were statistically significant. Mukesh et al. (2000) stated that when boron is applied at $4 \mathrm{~kg} / \mathrm{ha}$ number of flowers/plant was increased.

Number of seeds/umbel. Data regarding the number of seeds/umbel of onion are stated in Table 2. It is clear from the statistical analysis of the data that number of seeds is significantly affected by both $\mathrm{Zn}$ and $\mathrm{B}$. Statistically variation in the number of seeds/umbel was highly significant due to the effect of zinc. The maximum number of seeds/umbel (938.16) were recorded at 0.7 $\mathrm{kg} / \mathrm{ha}$ of zinc and the lower number (774.78) were obtained where $\mathrm{Zn}$ was applied at the rate of $0 \mathrm{~kg} / \mathrm{ha}$. Khan et al. (2007) obtained higher 15 number of seeds/umbel when applied zinc at the rate of $5 \mathrm{~kg} / \mathrm{ha}$. In case of boron, statistically highly significant variations in the number of seeds/umbel were observed due to the effect of boron. The highest number of seeds/umble (1019.7) were found with the application of $0.3 \mathrm{~kg} / \mathrm{ha}$ boron and the lowest number (693.9) were recorded from the control. Chattopadhyay and Mukhopadhyay (2004) also reported that number of seeds/umbel increased with the application of boron at higher dose. The variation in the number of seeds/umbel was statistically significant due to interaction effects of zinc and boron. The maximum number of seeds/umbel (1103.7) was found at the combination of $0.7 \mathrm{~kg} / \mathrm{ha}$ zinc and $0.3 \mathrm{~kg} / \mathrm{ha}$ boron and the minimum number (640.4) was recorded from control. Jana and Mukhopadhyay (2002) reported that number of seeds/umbel increased with the application of zinc and boron at higher dose.

Seeds weight (g)/umbel. Data regarding the seeds weight (g)/umbel of onion are given in Table 2. It was obtained from the analysis of the data that both $\mathrm{Zn}$ and $\mathrm{B}$ have significant effect on seeds weight (g)/umbel. Statistical variation in the seeds weight $(\mathrm{g}) / \mathrm{umbel}$ was highly significant due to the effect of zinc. Maximum seeds weight (g)/umbel (7.11) was recorded at $0.7 \mathrm{~kg} / \mathrm{ha}$ of zinc and the lower weight (4.94) was obtained where $\mathrm{Zn}$ was applied at the rate of $0 \mathrm{~kg} / \mathrm{ha}$. Khan et al. (2007) obtained higher seeds weight $(\mathrm{g}) / \mathrm{umbel}$ with the application of zinc at the rate of $5 \mathrm{~kg} / \mathrm{ha}$. In case of boron statistically significant variation in the seeds weight $(\mathrm{g}) / \mathrm{umbel}$ was observed due to the effect of boron. The highest seeds weight (g)/umbel (7.59) was found when $0.3 \mathrm{~kg} / \mathrm{ha}$ boron was applied and the lowest seeds weight (g)/umbel (4.82) was recorded from the control. Rashid et al. (2007) also reported that if boron is used at $5 \mathrm{~kg} / \mathrm{ha}$ increased seeds weight $(\mathrm{g}) / \mathrm{umbel}$. The variation in the seeds weight $(\mathrm{g}) / \mathrm{umbel}$ was 
statistically significant due to the interaction effect of zinc and boron.

Seeds yield $\mathbf{k g} / \mathbf{h a}$. The data pertaining to the seeds yield were analyzed and shown in Table 2 . Results showed that both $\mathrm{Zn}$ and B have significantly affected the seeds yield. Onion seed yield was significantly influenced by the application of zinc. The maximum seed yield (821.67 $\mathrm{kg} / \mathrm{ha}$ ) was found with the application of $0.7 \mathrm{~kg} / \mathrm{ha} \mathrm{Zn}$. Howlader et al. (2010) reported increased seed yield per hectare by additional zinc application. Similarly seed yield was significantly influenced by the effect of boron. The maximum seeds yield ( $866 \mathrm{~kg} / \mathrm{ha})$ was recorded from the application of $0.3 \mathrm{~kg} / \mathrm{ha}$ boron and minimum seeds yield $(723.00 \mathrm{~kg} / \mathrm{ha})$ was recorded when boron was applied at $0 \mathrm{~kg} / \mathrm{ha}$. Chowdhury et al. (2004) also reported that seeds yield increased with the application of boron at higher dose. Moreover, Robinowite et al. (2002) showed that foliar sprays of boron improved onion seeds yield.

Effect of $\mathrm{Zn}$ and $B$ foliar application on the concentration of zinc of onion leaf. Data regarding the concentration of zinc in leaves of onion are presented in Table 3. Maximum concentration of zinc (37.92 $\mathrm{mg} / \mathrm{kg}$ ) was obtained when zinc was applied at the rate

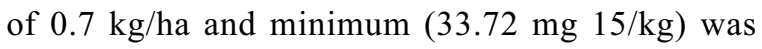
obtained when zinc was applied at the rate of $0 \mathrm{~kg} / \mathrm{ha}$. In case of boron maximum concentration of leaf zinc was obtained by B at the rate of $0.3 \mathrm{~kg} / \mathrm{ha}(44.69 \mathrm{mg} / \mathrm{kg})$, while minimum concentration $(18.29 \mathrm{mg} / \mathrm{kg})$ was obtained when boron was applied at the rate $0 \mathrm{~kg} / \mathrm{ha}$. Interaction effect of zinc and boron on the $\mathrm{Zn}$ concentration of leaf was statistically significant. The maximum concentration $(46.83 \mathrm{mg} / \mathrm{kg}$ ) of $\mathrm{Zn}$ was obtained by the combined application of zinc and boron at the rate of $0.7 \mathrm{~kg} / \mathrm{ha}$ and $0.3 \mathrm{~kg} / \mathrm{ha}$, respectively, while the minimum concentration $(14.37 \mathrm{mg} / \mathrm{kg})$ of leaf zinc was obtained from control. Shelp and Shattuck (1987) also determined a small change in the $\mathrm{Zn}$ translocation of radish plants because of boron. The level of zinc concentration obtained in our study is similar with the early work of Jones et al. (1991). These authors suggested that $25-100 \mathrm{mg} / \mathrm{kg}$ as sufficient concentration of $\mathrm{Zn}$ on the top of onion crop.

Effect of $\mathrm{Zn}$ and $\mathrm{B}$ foliar application on the concentration of boron of onion leaf. Data showed that both zinc and boron have significant effect on the concentration of leaf boron of onion. When boron was applied at $0.3 \mathrm{~kg} / \mathrm{ha}$ maximum concentration of boron $(45.64 \mathrm{mg} / \mathrm{kg})$ was obtained and minimum $(29.44 \mathrm{mg} / \mathrm{kg})$ was obtained when boron was applied at the rate of 0 $\mathrm{kg} / \mathrm{ha}$. In case of zinc maximum concentration of leaf boron was obtained by $\mathrm{Zn}$ at the rate of $0.7 \mathrm{~kg} / \mathrm{ha}(42.70$ $\mathrm{mg} / \mathrm{kg})$, while minimum concentration $(31.15 \mathrm{mg} / \mathrm{kg})$ was obtained when zinc was applied at the rate of 0 $\mathrm{kg} / \mathrm{ha}$. Interaction effect of zinc and boron on the boron concentration of leaf was statistically significant. When

Table 2. Effect of foliar application of $\mathrm{Zn}$ and B on yield and yield parameters of onion

\begin{tabular}{|c|c|c|c|c|c|c|}
\hline Foliar application & $\begin{array}{l}\text { Number of } \\
\text { leaves }\end{array}$ & $\begin{array}{l}\text { Days to } \\
\text { flowering }\end{array}$ & $\begin{array}{l}\text { Number of } \\
\text { flowers/plant }\end{array}$ & $\begin{array}{l}\text { Number of } \\
\text { seeds /umbel }\end{array}$ & $\begin{array}{l}\text { Seed weight/ } \\
\text { umbel (g) }\end{array}$ & $\begin{array}{l}\text { Seed yield } \\
(\mathrm{kg} / \mathrm{ha})\end{array}$ \\
\hline \multicolumn{7}{|l|}{ Zn level (kg/ha) } \\
\hline 0.1 & $48.40 \mathrm{~b}$ & $175.33 \mathrm{a}$ & $18.21 \mathrm{~b}$ & $774.78 \mathrm{c}$ & $4.94 c$ & $763.33 \mathrm{c}$ \\
\hline 0.3 & $50.90 \mathrm{a}$ & $170.00 \mathrm{~b}$ & $18.57 \mathrm{~b}$ & $860.54 b$ & $6.02 \mathrm{~b}$ & $780.78 b$ \\
\hline 0.7 & $52.54 \mathrm{a}$ & $171.22 b$ & $19.44 \mathrm{a}$ & $938.16 \mathrm{a}$ & 7.11a & $821.67 \mathrm{a}$ \\
\hline \multicolumn{7}{|l|}{ B level (kg/ha) } \\
\hline 0 & $45.83 \mathrm{c}$ & $175.78 \mathrm{a}$ & $17.08 \mathrm{c}$ & $693.92 \mathrm{c}$ & $4.82 \mathrm{c}$ & $723.00 \mathrm{c}$ \\
\hline 0.1 & $49.89 \mathrm{~b}$ & $173.78 \mathrm{a}$ & $18.97 \mathrm{~b}$ & $859.83 b$ & $5.67 \mathrm{~b}$ & $776.67 b$ \\
\hline 0.3 & $56.12 \mathrm{a}$ & $167.00 \mathrm{~b}$ & $20.18 \mathrm{a}$ & $1019.72 \mathrm{a}$ & $7.59 \mathrm{a}$ & $866.11 \mathrm{a}$ \\
\hline \multicolumn{7}{|l|}{ Interaction effect } \\
\hline $\mathrm{Zn} 0 * \mathrm{~B} 0$ & 43.83 & 181.67 & 16.2 & 640.37 & 4.13 & 693.33 \\
\hline $\mathrm{Zn} 0.3 * \mathrm{~B} 0$ & 46.27 & 171.33 & 17 & 714.37 & 5.27 & 725.67 \\
\hline $\mathrm{Zn} 0.7 * \mathrm{~B} 0$ & 47.4 & 174.33 & 18.03 & 727.03 & 5.07 & 750 \\
\hline $\mathrm{Zn} 0 * \mathrm{~B} 0.1$ & 48.33 & 176 & 18.47 & 737 & 4.67 & 755 \\
\hline Zn $0.3 *$ B 0.1 & 50.83 & 172 & 19.27 & 858.77 & 4.9 & 766.67 \\
\hline Zn $0.7 *$ B 0.1 & 50.5 & 173.33 & 19.17 & 983.73 & 7.43 & 808.33 \\
\hline $\mathrm{Zn} 0 *$ B 0.3 & 53.03 & 168.33 & 19.97 & 946.97 & 6.03 & 841.67 \\
\hline Zn $0.3 *$ B 0.3 & 55.6 & 166.67 & 19.43 & 1008.5 & 7.9 & 850 \\
\hline Zn $0.7 *$ B 0.3 & 59.73 & 166 & 21.13 & 1103.7 & 8.83 & 906.67 \\
\hline
\end{tabular}

*Means followed by different alphabets are statistically different from one another at $\mathrm{p}<0.5$. 
zinc and boron was combinely applied at $0.7 \mathrm{~kg} / \mathrm{ha}$ and $0.3 \mathrm{~kg} / \mathrm{ha}$, respectively, maximum concentration (53.32 $\mathrm{mg} / \mathrm{kg}$ ) of boron was obtained. While the minimum concentration $(18.22 \mathrm{mg} / \mathrm{kg})$ of leaf boron was obtained from control. Due to boron toxicity Singh et al. (1990) found $\mathrm{B}-\mathrm{Zn}$ interaction in the plants.

Effect of $\mathrm{Zn}$ and $\mathrm{B}$ foliar application on the concentration of zinc of onion seeds. It is clear from Table 3 that the concentration of seeds zinc of onion has significantly affected by both zinc and boron. Maximum concentration $(29.90 \mathrm{mg} / \mathrm{kg})$ of zinc was obtained when zinc was applied at the rate of $0.7 \mathrm{~kg} / \mathrm{ha}$. In case of boron maximum concentration of seeds zinc was obtained by $B$ at the rate of $0.3 \mathrm{~kg} / \mathrm{ha}(32.22 \mathrm{mg} / \mathrm{kg})$ while minimum concentration $(20.38 \mathrm{mg} / \mathrm{kg})$ was obtained when boron was applied at the rate of $0 \mathrm{~kg} / \mathrm{ha}$. Interaction effect of zinc and boron on the $\mathrm{Zn}$ concentration of seeds was statistically significant. The maximum concentration $(36.93 \mathrm{mg} / \mathrm{kg}$ ) of $\mathrm{Zn}$ was obtained by the combined application of zinc and boron at the rate of $0.7 \mathrm{~kg} / \mathrm{ha}$ and $0.3 \mathrm{~kg} / \mathrm{ha}$, respectively, while the minimum $(15.1 \mathrm{mg} / \mathrm{kg})$ seed zinc was obtained from control. In literature critical level of zinc in plant parts like seed is not properly discussed. Like other parts of the crop seed is also taken as diagnostic part for better analytical precision (Rashid and Fox, 1992). The concentration of zinc in seeds obtained in our study

Table 3. Effect of foliar application of $\mathrm{Zn}$ and B on the concentration of $\mathrm{Zn}$ and $\mathrm{B}$ in leaf and seed of onion

\begin{tabular}{|c|c|c|c|c|}
\hline $\begin{array}{l}\text { Foliar application } \\
\text { Zn level (kg/ha) }\end{array}$ & $\begin{array}{l}\text { Leaf Zn } \\
(\mathrm{mg} / \mathrm{kg})\end{array}$ & $\begin{array}{l}\text { Leaf B } \\
(\mathrm{mg} / \mathrm{kg})\end{array}$ & $\begin{array}{l}\text { Seed Zn } \\
(\mathrm{mg} / \mathrm{kg})\end{array}$ & $\begin{array}{l}\text { Seed B } \\
(\mathrm{mg} / \mathrm{kg})\end{array}$ \\
\hline 0.1 & $33.72 \mathrm{c}$ & $31.15 \mathrm{c}$ & $19.37 \mathrm{c}$ & 25.99 \\
\hline 0.3 & $35.18 b$ & $36.93 b$ & $26.59 b$ & 28.57 \\
\hline 0.7 & $37.92 \mathrm{a}$ & $42.70 \mathrm{a}$ & $29.90 \mathrm{a}$ & 32.82 \\
\hline \multicolumn{5}{|l|}{ B level (kg/a) } \\
\hline 0 & $18.29 \mathrm{c}$ & $29.44 \mathrm{c}$ & $20.38 \mathrm{c}$ & $21.53 \mathrm{c}$ \\
\hline 0.1 & $43.83 b$ & $35.70 \mathrm{~b}$ & $23.27 \mathrm{~b}$ & $32.14 b$ \\
\hline 0.3 & $44.69 \mathrm{a}$ & $45.64 \mathrm{a}$ & $32.22 \mathrm{a}$ & $33.71 \mathrm{a}$ \\
\hline \multicolumn{5}{|l|}{ Interaction effect } \\
\hline $\mathrm{Zn} 0 * \mathrm{~B} 0$ & 14.37 & 18.22 & 15.1 & 12.13 \\
\hline $\mathrm{Zn} 0.3 * \mathrm{~B} 0$ & 15.88 & 32.86 & 22.85 & 25.99 \\
\hline $\mathrm{Zn} 0.7 * \mathrm{~B} 0$ & 24.63 & 37.22 & 23.18 & 26.47 \\
\hline $\mathrm{Zn} 0 * \mathrm{~B} 0.1$ & 44.68 & 35.55 & 17.35 & 35.13 \\
\hline Zn $0.3 *$ B 0.1 & 44.57 & 33.98 & 22.87 & 29.46 \\
\hline $\mathrm{Zn} 0.7 *$ B 0.1 & 42.25 & 37.56 & 29.58 & 31.82 \\
\hline $\mathrm{Zn} 0 * \mathrm{~B} 0.3$ & 42.1 & 39.68 & 25.65 & 30.72 \\
\hline Zn $0.3 *$ B 0.3 & 45.1 & 43.93 & 34.07 & 30.25 \\
\hline $\mathrm{Zn} 0.7 *$ B 0.3 & 46.88 & 53.32 & 36.93 & 40.17 \\
\hline
\end{tabular}

*Means followed by different alphabets are statistically different from one another at $\mathrm{p}<0.5$. is similar with the findings of Jones et al. (1991) who stated that 25 to $100 \mathrm{mg} / \mathrm{kg}$ as sufficient concentration of $\mathrm{Zn}$ in the top of onion crops. Similar to leaf concentration of zinc the seeds concentration was also correlated with applied foliar zinc.

Effect of $\mathrm{Zn}$ and $\mathrm{B}$ foliar application on the concentration of seeds boron of onion seed. The data revealed that both zinc and boron have significant effect on the concentration of seeds boron of onion. Maximum concentration of boron $(33.71 \mathrm{mg} / \mathrm{kg}$ ) was obtained when boron was applied at the rate of $0.3 \mathrm{~kg} / \mathrm{ha}$ and minimum $(21.53 \mathrm{mg} / \mathrm{kg})$ was obtained when boron was applied at the rate of $0 \mathrm{~kg} / \mathrm{ha}$. Significant variations were found among the treatment plots. In case of zinc maximum concentration of seeds boron was obtained by $\mathrm{Zn}$ at the rate $0.7 \mathrm{~kg} / \mathrm{ha}(32.82 \mathrm{mg} / \mathrm{kg})$, while minimum concentration $(25.99 \mathrm{mg} / \mathrm{kg})$ was obtained when zinc was applied at the rate of $0 \mathrm{~kg} / \mathrm{ha}$. Interaction effect of zinc and boron on the boron concentration of seeds was statistically significant. The maximum concentration $(40.17 \mathrm{mg} / \mathrm{kg})$ of boron was obtained by the combined application of zinc and boron at the rate of $0.7 \mathrm{~kg} / \mathrm{ha}$ and $0.3 \mathrm{~kg} / \mathrm{ha}$, respectively, while the minimum $(12.13 \mathrm{mg} / \mathrm{kg})$ concentration of seeds boron was obtained from control.

Singh et al. (1990) found B-Zn interaction in the plants due to boron excess. In the present experiment all the treatment plots showed adequate level of boron as reported by Howlader et al. (2010). Results further indicated that as the applied foliar boron increases, seeds boron also linearly and significantly increased with all levels of applied zinc and showed close relationship to one another. However, the concentration of leaf boron considerably reduced with the initial level of applied zinc, indicating zinc played a protecting role against the excess boron accumulations in the seeds of onion crop. Similar results were reported by Tariq et al. (2005); Singh et al. (1990) and Graham et al. (1987).

\section{Conclusion}

The present experiment indicates that the yield and yield parameters of onion crop significantly affected by the applied foliar spray of zinc-boron. The concentrations of zinc and boron in leaves at flowering stage as well as in seeds at harvest of onion crop also significantly affected by the applied foliar spray of zincboron. Linear regression models suggest that zinc-boron interactions are significant in terms of leaf and seed 
concentrations of onion crop. Thus, the combined application of zinc and boron as foliar spray at the rate of 0.7 and $0.3 \mathrm{~kg} / \mathrm{ha}$ at the time of 150 days after sowing improved the yield and yield parameters and enhanced micronutrients concentration in leaves and in seeds of onion crop which in turn improves the assimilates transfer and poses positive impact on seed yield of onion.

Conflict of Interest. The authors declare no conflict of interest

\section{References}

Bingham, F.T. 1982. Boron. In: Methods of Soil Analysis Part 2. Chemical and Microbiological Properties. pp. 431-228. American Society of Agronomy, Madison, Wisconsin, USA.

Chattopadhyay, A., Mukhopadhyay, R. 2004. Response of onion to boron and molybdenum as foliar feeding. Environment and Ecology, 22: 784-787.

Chowdhury, S.H., Ali, M.S., Hossain, M.A., Ahmed, M.U, Haque, M.M. 2004. Effect of boron and sulphur on yield and quality of onion seed. Bangladesh Journal of Agricultural Sciences, 22: 179-184.

FAO, 2014. Food and Agricultural Organization of the United Nations. Bulletin No. 48: Rome, Italy.

Graham, R.D., Welch, R.H., Gruens, D.L., Cary, E.E., Norvell, W.A. 1987. Effect of zinc deficiency on the accumulation of boron and other mineral nutrients in barley. Soil Science Society of America Journal, 51: 652-667.

Howlader, M.M., Kamruzzaman, M. M., Chowdhury, M.E.K., Yousaf, M.N. 2010. Effect of phosphorus, potassium and boron on onion seed production. Research Report. pp. 13-17. Spices Research Centre. Bangladesh Agricultural Research Institute, Bangladesh

Isaac, R.A., Kerber, J.D. 1971. Atomic absorption and flame photometry: Techniques and uses in soil, plant and water analysis. In: Instrumental Methods for Analysis of Soils and Plants Tissue, L.M. Walsh, (ed.) pp: 17-37, Soil Science Society of America Madison, WI, USA.

Jana, B.K., Mukhopadhaya, J. 2002 . Effect of boron, molybdenum and zinc on yield and quality of onion seed. Crops Research, 3: 241-243.

Jones, J.B., Wolf, B., Mills, H.A. 1991. Zinc in Crop Nutrition. Plant Analysis Hand Book, pp:126-129.
Micro-Macro Publishing, Inc. Athens, GA, USA.

Khan, A.M., Rashid, A.M., Ullah, M.A. 2007. Effect of sulphur and zinc on onion seed production. Research Report. pp. 14-19. Spices Research Centre, Bangladesh Agricultural Research Institute, Bangladesh.

Lanzotti, V. 2006. The analysis of onion and garlic. Journal of Chromatography, 1112: 3-22.

Liew, C.S. 1988. Foliar fertilizers from Uniroyal and their potential in Pakistan. Proceedings of Seminar on Micronutrient in Soils and Crops in Pakistan, pp. 277.

Mishra, H.P., Singh, K.P., Yadow, J.P. 1990. Influence of zinc, iron, boron and manganese and their uptake on onion (Allium cepa L.) growth in calcareous soil. Haryana Journal of Horticultural Sciences, 19: 153-159.

Mukesh, K., Das, D.K., Chattopadhyay, T.K., Mukesh, M. 2000. Effect of zinc and sulfur application on yield and quality of onion (Allium cepa L.). Environmental Ecology, 18: 561-565.

Munir, H. Z., Ahmad, R., Khaliq, I., Ahmad, A., Irshad, M. 2006. Micronutrients status and management in orchards soils: Applied Aspects, Soil \& Environment, 25: 6-16.

Rashid, A., Fox, R.L. 1992. Evaluating internal zinc requirement of grain crops by seed analysis. Agronomy Journal, 84: 469-474.

Rashid, A.M ., Khan, A.M., Ullah, M.A. 2007. Effect of sulphur and boron on onion seed production. Research Report, pp. 5-9, Spices Research Centre, Bangladesh Agricultural Research Institute, Bangladesh.

Robinowitch, H.D., Currah, L. 2002. Allium Crop Science: Recent Advances, pp. 218, CABI International, UK.

Ryan, I., Estefan, G., Rashid, A. 2001. Soil and Plant Analysis. Laboratory Manual. $2^{\text {nd }}$ edition. ICARDA, Syria.

Shaikh, A.M., Vyakaranahal, B.S., Shekhargouda, M., Dharmatti, P.R. 2002. Influence of bulb size and growth regulators on growth, seed yield and quality of onion cv. Nasik Red. Seed Research, 30: 223-229.

Shelp, B.J., Shattuck, V.I. 1987. Boron nutrition and mobility and its relation to the elemental composition of greenhouse grown root crops. II. Radish. Communication in Soil Science and Plant Analysis, 18: 203-219. 
Silberbush, L.F. 2002. Response of maize to foliar vs. soil application of nitrogen phosphorus-potassium fertilizers. Journal of Plant Nutrition, 25: 23332342.

Sillanpaa, M. 1982. Micronutrients and nutrients status of soil. A global study. FAO Soil Bulletin, No.48, Rome, Itly.

Singh, H. 1990. Effect of Soil and Foliar Application of Boron and Zinc on Yield and Quality of Radish Seed Crop ( Raphanus sativus L.) cv. Japanes white. M.Sc Thesis. Department of Vegetable Crops, University of Horticulture and Forestry, Nauni, Solan, India.
Steel, R.G.D., Torrie, J.H., Dicky, D.A. 1997. Principles and Procedures of Statistics, A Biometrical Approach. pp. 352-358. $3^{\text {rd }}$ edition, McGraw Hill, Inc. Book Co., New York, USA.

Sultanpour, P.N., Schawab, A.P. 1977. A new soils test simultaneous extraction of macro and micronutrients in alkaline soils. Communication in Soil Science and Plant Analysis, 8: 195-207.

Tariq, M., Kakar, K.M., Shah, Z. 2005. Effect of boronzinc interaction on the yield, yield attributes and availability of each to wheat (Triticum aestivum L.) grown on calcareous soils. Soil and Environment, 24: 103-108. 